\title{
Nearshore Distribution and an Abundance Estimate for Green Sea Turtles, Chelonia mydas, at Rota Island, Commonwealth of the Northern Mariana Islands ${ }^{1}$
}

\author{
Steven P. Kolinski, ${ }^{2}$ Ronald K. Hoeke, ${ }^{3}$ Stephani R. Holzwarth, ${ }^{3}$ Larry I. Ilo, ${ }^{4}$ Evelyn F. Cox,${ }^{2}$ \\ Robert C. O'Conner, ${ }^{2}$ and Peter S. Vroom ${ }^{3}$
}

\begin{abstract}
Seventy-three green turtles, Chelonia mydas (Linnaeus, 1758), were observed in 84 sightings along 28 transects covering $67 \%$ of Rota's shoreline and outer reef perimeter in the Commonwealth of the Northern Mariana Islands. No other sea turtle species were encountered. Juvenile turtles of various sizes dominated in all surveyed environments, and observations of turtles with estimated straight carapace lengths $\leq 40 \mathrm{~cm}$ suggested recent and continuing recruitment at Rota. Distribution of turtles appeared temporally stable when compared with previously reported observations and data, with turtle concentrations highest along northeast, east, and southeast coasts of the island. Approximately 118 turtles were projected to inhabit nearshore habitats at Rota. Although this population may appear minor and indistinct compared with those at nearby Tinian and Saipan, continued monitoring would be useful for comparison of Mariana Islands trends. Thirty-five species of cyanophytes, algae, and a sea grass noted as green turtle forage in other world regions were identified at Rota in this and previous surveys.
\end{abstract}

The green turtle, Chelonia mydas (Linnaeus, 1758), has been reported as the principal sea turtle species in the Commonwealth of the Northern Mariana Islands (CNMI) (Wiles et al. 1989, 1990, McCoy 1997, Pultz et al. 1999, Kolinski et al. 2001, 2004, 2005). Anecdotal observations and intermittent surveys suggest that nesting greens make up a relatively small proportion of the local sea turtle population, with known numbers of

\footnotetext{
${ }^{1}$ Manuscript accepted 20 December 2005.

${ }^{2}$ Joint Institute for Marine and Atmospheric Research, National Marine Fisheries Service, Pacific Islands Regional Office, 1601 Kapiolani Boulevard, Suite 1110, Honolulu, Hawai'i 96814-0047 (e-mail: steve.kolinski@ noaa.gov).

${ }^{3}$ Joint Institute for Marine and Atmospheric Research, National Marine Fisheries Service, Coral Reef Ecosystem Division, 1125B Ala Moana Boulevard, Honolulu, Hawai'i 96814.

${ }^{4}$ Division of Fish and Wildlife, Department of Lands and Natural Resources, P.O. Box 10007, Lower Base Area, Saipan, MP 96950.
}

Pacific Science (2006), vol. 60, no. 4:509-522

(C) 2006 by University of Hawai'i Press

All rights reserved annual nests ranging to the low tens throughout the commonwealth (Pritchard 1982, Wiles et al. 1989, 1990, McCoy 1997, Pultz et al. 1999, Ilo and Manglona 2001, Kolinski et al. 2001). The preponderance of turtles in the region are found residing in nearshore reef areas of the southern arc islands (Figure 1), where identification of distributions and abundance has become critical to ascertaining turtle population status and dynamics, particularly in relation to human activities that include efforts at resource management and recovery (National Marine Fisheries Service and U.S. Fish and Wildlife Service 1998, Kolinski et al. 2001, 2004, 2005; S.P.K., unpubl. data).

In 2003, surveys of reefs throughout the Mariana Archipelago off the NOAA ship R/ V Oscar Elton Sette included a rapid yet comprehensive assessment for turtles in nearshore marine habitats of the southernmost CNMI island, Rota. Few assessments for sea turtles in nearshore waters at Rota have been made (Wiles et al. 1990, Ilo and Manglona 2001), and published observations on turtle distributions and abundance for the island are limited (Wiles et al. 1990, Kolinski et al. 2004). Con- 


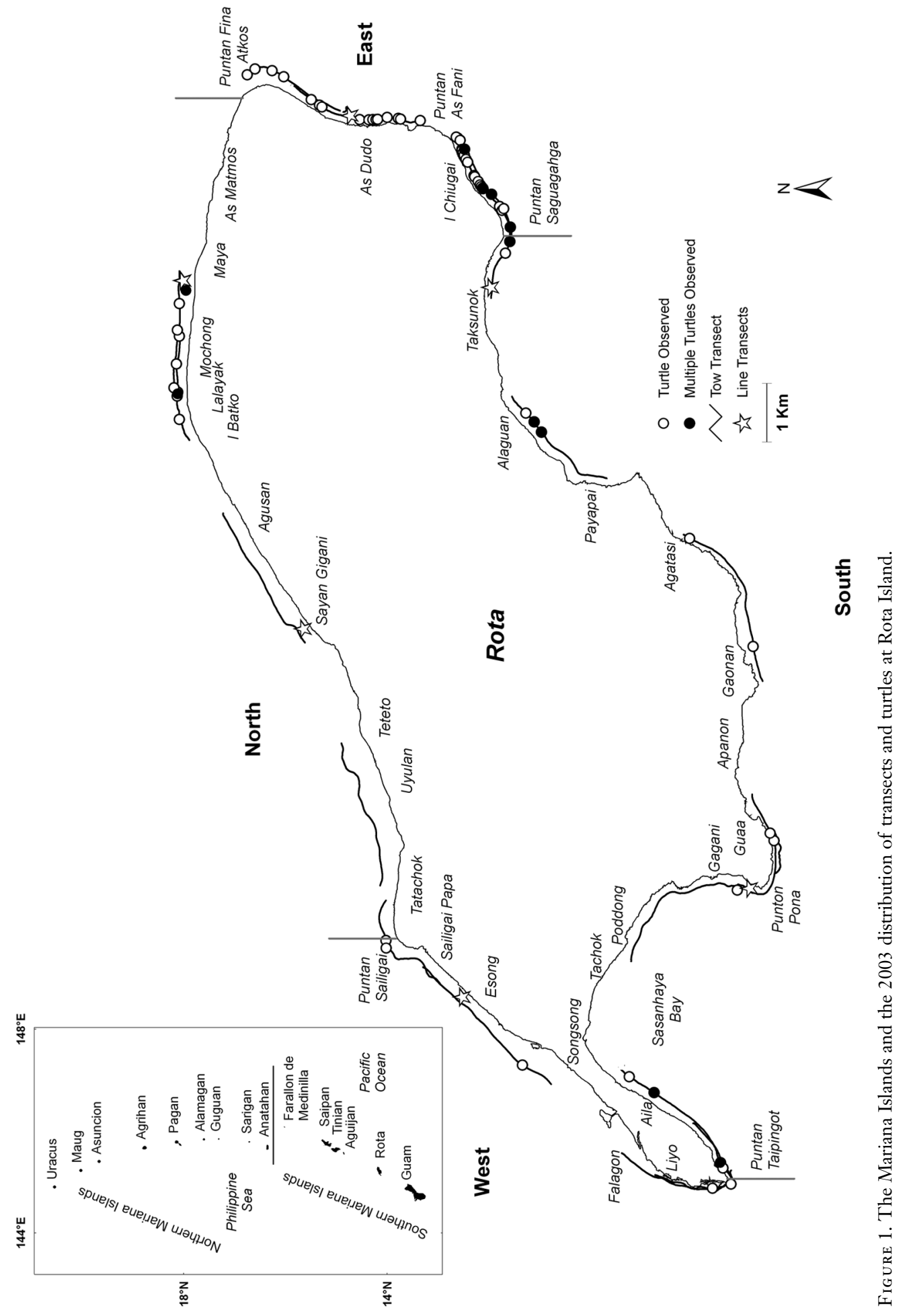


sistent with recommendations of the recovery plan for U.S. Pacific green turtle populations (National Marine Fisheries Service and U.S. Fish and Wildlife Service 1998), in this paper we present detailed information on turtle distributions, estimated size classes, projected abundance, and likely food resources for green turtles in marine habitats surrounding Rota Island.

\section{Study Area}

$\operatorname{Rota}\left(14^{\circ} 9^{\prime} \mathrm{N}, 145^{\circ} 12^{\prime} \mathrm{E}\right)$ is an $85-\mathrm{km}^{2}$ island located northeast of Guam $(60 \mathrm{~km})$ and southwest of Aguijan $(71 \mathrm{~km})$ in the southern arc of the Mariana Archipelago (Figure 1). The island consists of terraced limestone plateaus bordering two small volcanic outcrops and reaches $491 \mathrm{~m}$ in height (Eldredge 1983, Wells and Jenkins 1988, Wiles et al. 1990). Steep limestone cliffs, rocky shores, and intermittent benches characterize much of the eastern and southern coasts as well as the southern portion of the western peninsula. Coarse calcareous sand beaches are interspersed among rock along northern, southern, and western shores (Eldredge and Randall 1980), where sea turtle nesting has been reported as infrequent (Wiles et al. 1990, Grout 1997, McCoy 1997, Ilo and Manglona 2001). Marine habitats are diverse and include fringing reefs, shallow reef slopes, spur and groove zones, extensive pavement, boulder fields, ledges, and steep cliffs. Human development is concentrated mainly in the southwest of the island at Songsong (Figure 1). The 2000 census identified 3,283 residents (Evans et al. 2002), approximately $5 \%$ of the CNMI population. Fisheries resources at Rota are exploited by local and neighboring island residents.

\section{MATERIALS AND METHODS}

Assessments for turtles at Rota were conducted on 19 and 20 September 2003, off the NOAA ship R/V Oscar Elton Sette. Two survey methods were employed. Towed-diver surveys (Kenyon et al. in press) consisted of two scuba divers per boat being towed parallel to shore by each of two boats at depths ranging from 3 to approximately $30 \mathrm{~m}$. On one of the boats, when a turtle was sighted its approximate position was signaled to boat personnel via a magnetic-switch telegraph and recorded on a geographic positioning system (GPS) (Garmin 76S). On the other boat turtle positions were estimated by matching observation times with points collected every 5 sec on a GPS set to record tow tracks. Observation time, species, size (visually estimated straight carapace length [SCL] made in comparison with 1 -m-wide tow-boards delineated with 10-cm markings), sex (when discernable), activity, and habitat characteristics were recorded by underwater observers. Individual tows typically lasted $1 \mathrm{hr}$ and occurred at spatial intervals that allowed for characterization of all major (i.e., north, east, south, and west) coastlines (Figure 1). The second method consisted of dive surveys made between depths of 12 and $22 \mathrm{~m}$ by eight scientific divers who collected data on turtles while assessing fish, invertebrate, and algal communities along three $25-\mathrm{m}$ transects at each of six locations around the island. The dive survey data are presented to reflect consistency in observations of turtle distributions. However, they were not included in abundance estimates because most likely were resightings of turtles counted in tow surveys that overlapped these short transects. In all surveys, benthic habitats and the water column were assessed for turtles within ranges of visibility (typically 15 to $>40 \mathrm{~m}$ ). Surface waters also were searched by support boat personnel, with pertinent information on turtle sightings (as previously described) being recorded.

Turtle maturity status was not directly measured for any individual. Visual SCL estimates were used to grossly categorize turtles as juveniles $(\leq 70 \mathrm{~cm})$, juvenile/adults $(>70$ and $\leq 90 \mathrm{~cm}$ ), and presumed adults $(>90$ $\mathrm{cm})$. The range for "presumed adults" may appear liberal but was based on the average of mean SCL nesting sizes presented for Pacific turtles by Hirth (1997), rounded to the nearest decimeter. Estimated turtle numbers were adjusted for each transect by removing resightings of the same individual based on size, distinguishing features, time, and specific locations and/or routes. Such methods are 


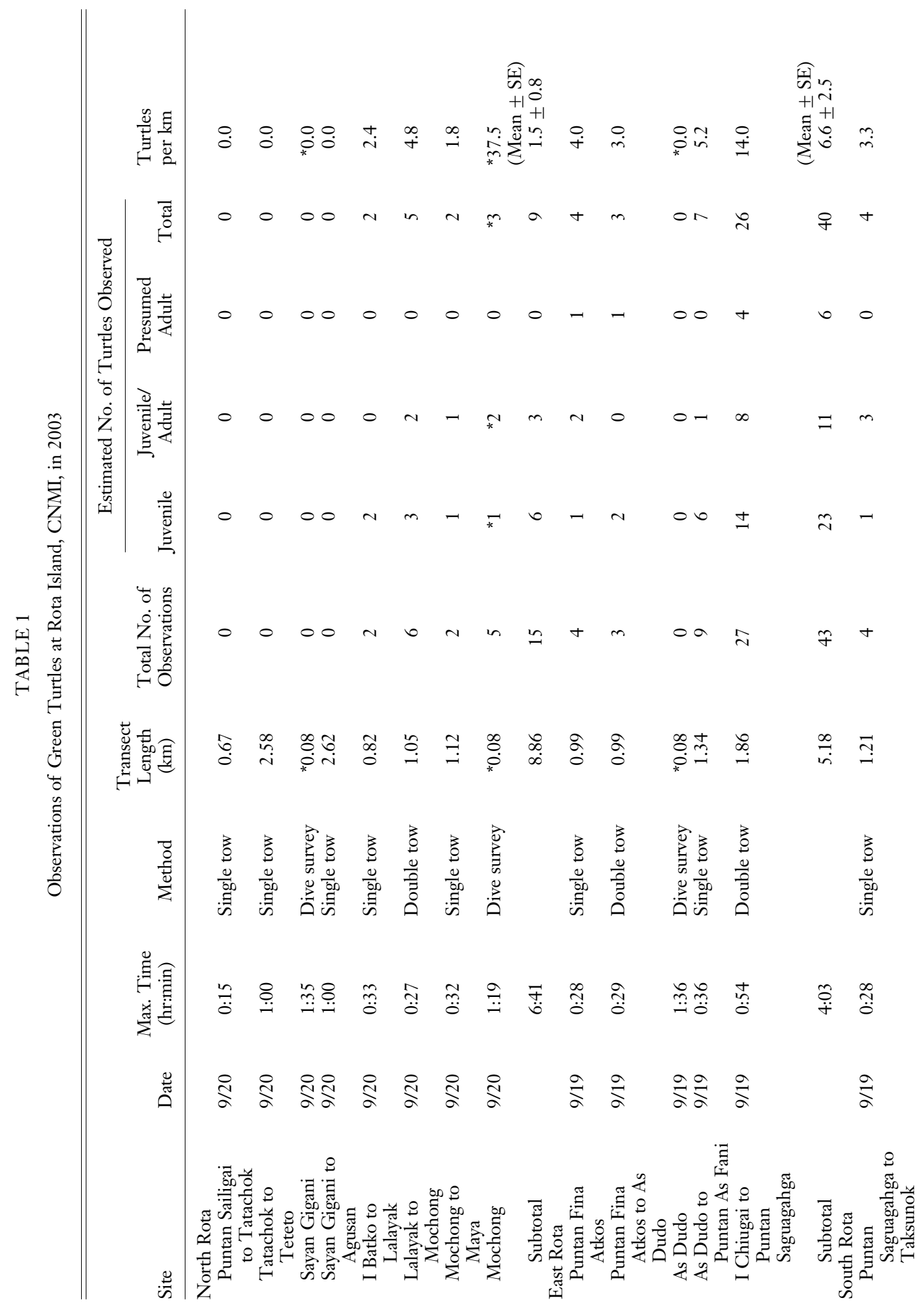




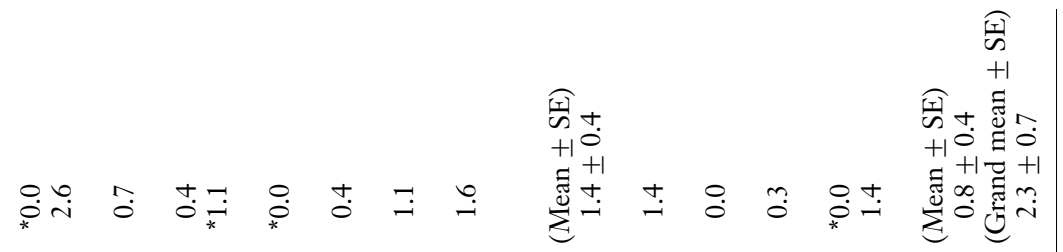

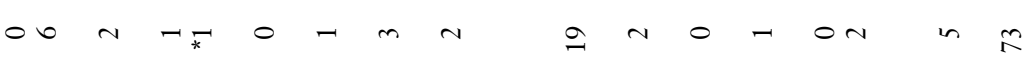

$$
\begin{aligned}
& \text { ON } 0 \text { O } \\
& 0 m 0000-0,0-1-0,000-4 \\
& 0-4-\vec{k} 0 \text { o n h }
\end{aligned}
$$

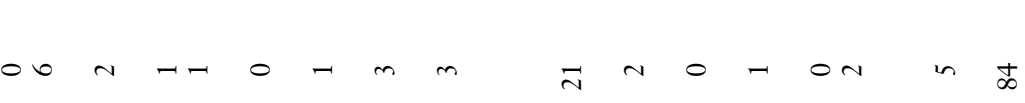

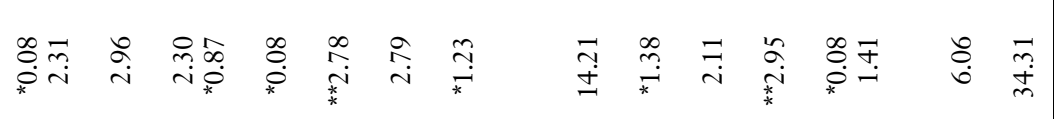

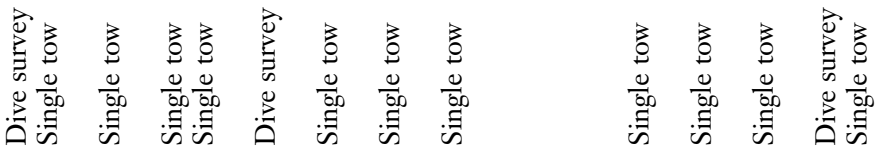

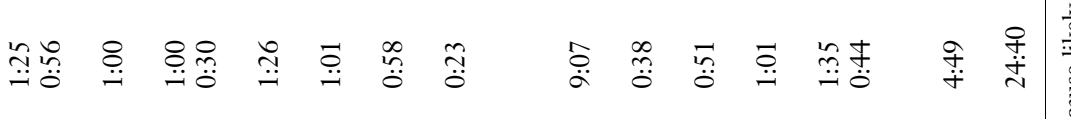

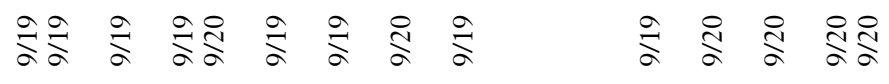

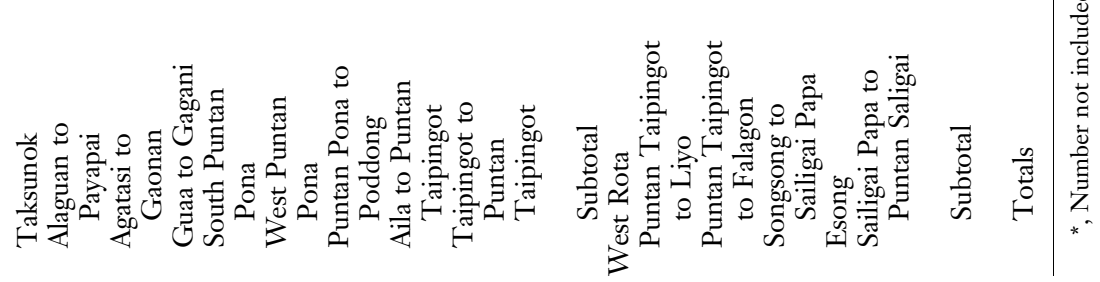


open, however, to potentially counting some individuals twice, particularly those observed at distance and lacking distinguishing features. Regional turtle abundance in Rota's nearshore waters was projected by multiplying the mean number of turtles per kilometer from surveyed transects by total kilometers in each region. Total abundance was determined using the mean of islandwide samples. No correction factor for single tows was used because the mean percentage increase in turtle numbers with double tows was zero (Kolinski et al. 2004). Upper boundaries of $95 \%$ confidence intervals were calculated for each region as well as islandwide using $t$ distributions.

Field identifications of algal and sea-grass species were conducted by P.S.V. using the algal sampling protocol described by Preskitt et al. (2004). The results were collated with those reported in the literature, and a species list of potential green turtle forage for Rota was compiled along with locations and references. Hirth (1997) and additional sources (Agastheesapillai and Thiagarajan 1979, Balazs 1980, 1985, Mortimer 1981, Mendonca 1983, Balazs et al. 1987, 1995, 2005, Burke et al. 1991, Limpus et al. 1994, 2005, Forbes 1996, Russell and Balazs 2000, Read and Limpus 2002, Seminoff et al. 2002, Calvo et al. 2003, Ferreira et al. 2003, LopezMendilaharsu et al. 2003, 2005, Russell et al. 2003, Searle 2003, Andre et al. 2005, Holloway-Adkins and Ehrhart 2005, Sanchez and Quiroga 2005, Sara et al. 2005, Uzcategui et al. 2005, Makowski et al. 2006) were used for guidance in listing only those species identified as turtle forage in other parts of the world.

\section{RESULTS}

Seventy-three individual green turtles were observed via 84 sightings along 28 transects covering $67 \%$ of Rota's $51 \mathrm{~km}$ of outer reef perimeter (Table 1, Figure 1). No other turtle species were encountered. Fifty-nine percent (43 turtles) of the turtles were juveniles, $30 \%$ (22 turtles) were classified as juvenile/ adult, and $11 \%$ (8 turtles) were categorized as presumed adults. Juveniles were the domi- nant size class on all coastlines. Presumed adults were observed in east- and south-coast habitats (Figure 2) and included four probable females (SCL $\geq 100 \mathrm{~cm}$ ) and three males. Four turtles had estimated SCLs $\leq 40 \mathrm{~cm}$, suggesting relatively recent recruitment to the resident population.

Twelve percent ( 9 turtles) of the turtles were observed in habitats on the north side of the island, $55 \%$ (40 turtles) on the east, $26 \%$ (19 turtles) at south-coast sites, and 7\% (5 turtles) along the west coast. Projected numbers and average densities of turtles for the entire perimeter of each coastal region are shown in Table 2 . The average projected density of turtles on the east coast was 4.4 and 4.7 times that of the north and south coasts, respectively, and 8.3 times that of the west coast. Turtle concentrations were highest along northeastern, eastern, and southeastern shorelines from Lalayak to Alaguan (Figure 1). The total number of green turtles inhabiting Rota's nearshore environments was projected to be approximately 118, with an upper estimate of 191 (95\% confidence interval) (Table 2).

The compilation of data from marine plant and algae surveys indicated the presence of at least 35 species of cyanophytes, algae, and a sea grass identified as green turtle forage in other parts of the world (Table 3). Three (9\%) of the species were cyanophytes, $11(31 \%)$ were chlorophytes, 8 (23\%) were phaeophytes, 12 (34\%) were rhodophytes, and one $(3 \%)$ was an anthophyte. Twentyfive $(71 \%)$ of the species were located at north-coast sites, 5 (14\%) along the east coast (only one site surveyed), $24(69 \%)$ on the south coast, and 25 (71\%) at west-coast sites. Additional Rota genera (Tsuda 2003, this study) that may be utilized by turtles include Calothrix, Microcystis, Avrainvillea, Chaetomorpha, Microdictyon, Udotea, Valonia, Dictyopteris, Rosenvingia, Amphiroa, Ceramium, Galaxaura, Gelidium, Hypoglossum, Laurencia, Liagora, and Polysiphonia.

\section{DISCUSSION}

The distribution of sea turtles at Rota was similar to that described in Wiles et al. 


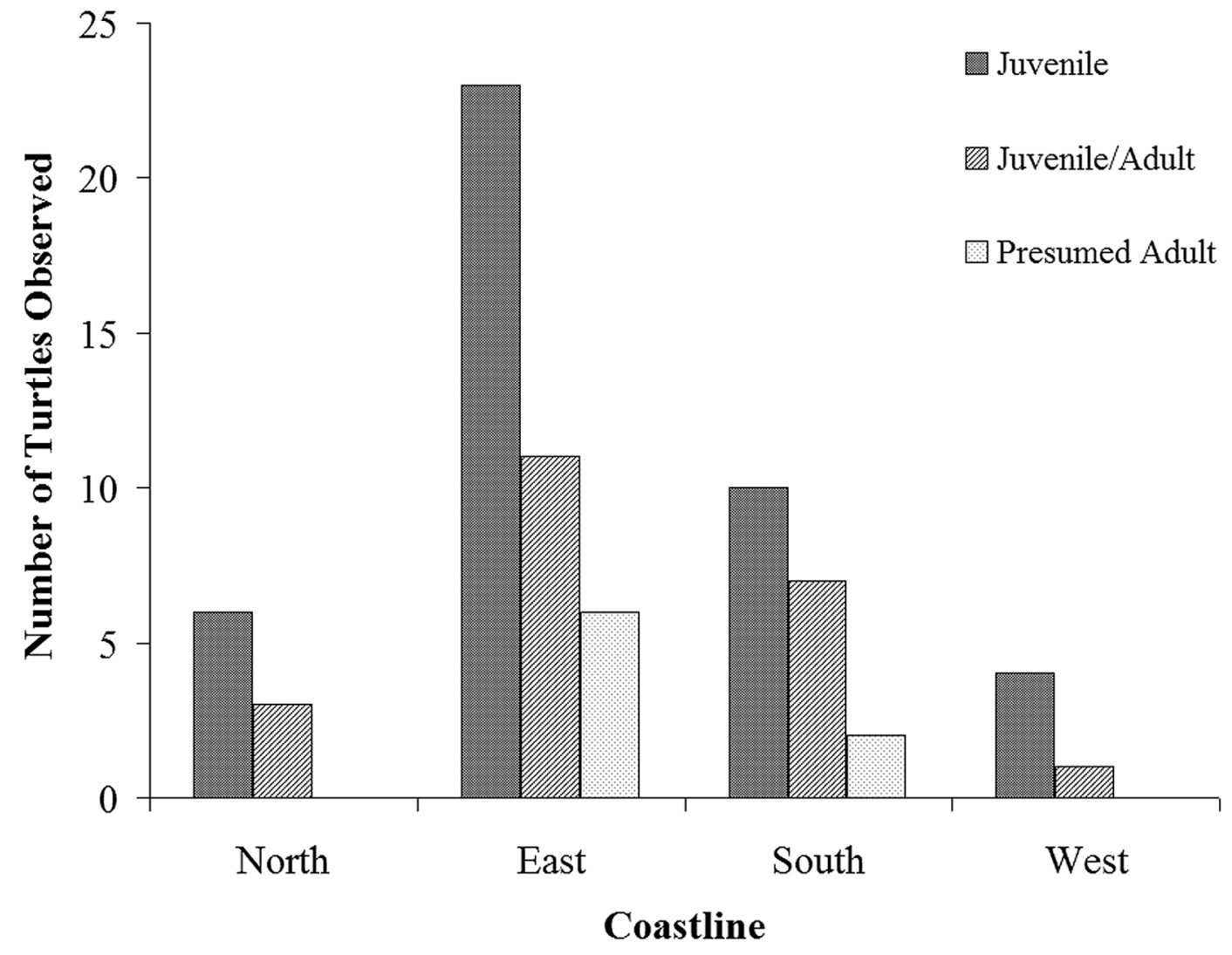

Figure 2. Estimated number of green turtles observed at Rota Island categorized by size and location.

TABLE 2

Projected Green Turtle Abundance by Region and Islandwide for Rota

\begin{tabular}{lccccc}
\hline \hline Region & $\begin{array}{c}\text { Total } \\
\text { Perimeter } \\
(\mathrm{km})\end{array}$ & $\begin{array}{c}\text { Perimeter } \\
\text { Surveyed } \\
(\%)\end{array}$ & $\begin{array}{c}\text { Average No. } \\
\text { Turtles/km } \\
( \pm \mathrm{SE})\end{array}$ & $\begin{array}{c}\text { Projected } \\
\text { No. of } \\
\text { Turtles }\end{array}$ & $\begin{array}{c}\text { Upper 95\% } \\
\text { Confidence } \\
\text { Interval Boundary }\end{array}$ \\
\hline North & 15.2 & 58.4 & $1.5 \pm 0.8$ & 23 & 54 \\
East & 6.3 & 82.7 & $6.6 \pm 2.5$ & 41 & 92 \\
South & 22.1 & 64.3 & $1.4 \pm 0.4$ & 32 & 55 \\
West & 7.7 & 78.7 & $0.8 \pm 0.4$ & 6 & 15 \\
Islandwide & 51.3 & 67.0 & $2.3 \pm 0.7$ & 118 & 191 \\
\hline
\end{tabular}

(1990), with concentrations highest along the northeastern, eastern, and southeastern coasts of the island. Similarly, the distribution appeared consistent with observations and data provided by Ilo and Manglona (2001) in areas where survey overlap occurred. Temporal consistency in the general distribution suggests stability in Rota's habitat availability and utilization by turtles but also may reflect illegal harvesting pressure, with limited access for poaching along trade-wind coasts. Similar distributions favoring east-coast habitats have 
TABLE 3

Rota Marine Algae Listed by Hirth (1997) and Additional Sources (See Text) as Green Turtle Forage

\begin{tabular}{|c|c|}
\hline Classification & Location and Reference \\
\hline \multicolumn{2}{|l|}{ Cyanophyta } \\
\hline Hormothamnium entermorphoides Grunow & $\begin{array}{l}\text { Uyulan }^{9} \text {, North Rota; Gaonan }{ }^{1} \text {, Apanon, Gagani }{ }^{8} \text {, South Rota; } \\
\text { Puntan Sailigai, Falagon }{ }^{1} \text {, West Rota }\end{array}$ \\
\hline $\begin{array}{l}\text { Microcoleus lyngbyaceus (Kutzing) } \\
\text { Anagnostidis \& Komarek }\end{array}$ & $\begin{array}{l}\text { Teteto area }{ }^{1} \text {, North Rota; Gaonan, Sasanhaya Bay }{ }^{1}, \text { Apanon }^{8} \text {, } \\
\text { South Rota; Puntan Sailigai }{ }^{1}, \text { Falagon }{ }^{1} \text {, West Rota }\end{array}$ \\
\hline Schizothrix calcicola (C. Agardh) Gomont & $\begin{array}{l}\text { Teteto area, Tatachok }{ }^{1}, \text { Mochon-As Matmos area }^{6} \text {, North Rota; } \\
\text { Gaonan, Sasanhaya Bay }{ }^{1} \text {, Apanon, Gagani }{ }^{8} \text {, South Rota; } \\
\text { Puntan Sailigai }{ }^{1} \text {, West Rota }\end{array}$ \\
\hline \multicolumn{2}{|l|}{ Chlorophyta } \\
\hline Bryopsis pennata Lamouroux & $\begin{array}{l}\text { Uyulan }^{9} \text {, Teteto area }{ }^{1}, \text { Mochong-As Matmos } \text { area }^{6} \text {, North Rota; } \\
\text { West Punton Pona }{ }^{12} \text {, South Rota; Puntan Sailigai }{ }^{1} \text {, West Rota }\end{array}$ \\
\hline Caulerpa cupressoides (West) C. Agassiz & $\begin{array}{l}\text { Uyulan }^{9} \text {, North Rota; Gagani } \\
\text { Sailigai }{ }^{1} \text {, Sest Roth Rota; Falagon }{ }^{1} \text {, Puntan }\end{array}$ \\
\hline Caulerpa racemosa (Forsskål) J. Agassiz & 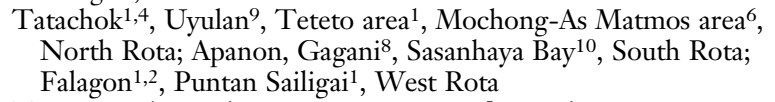 \\
\hline Caulerpa serrulata (Forsskål) J. Agardh & $\begin{array}{l}\text { Teteto area }{ }^{1} \text {, Mochong-As Matmos area }{ }^{5}, \text { North Rota; } \\
\text { Puntan Sailigai }{ }^{1} \text {, West Rota }\end{array}$ \\
\hline Caulerpa urvilliana Montagne & $\begin{array}{l}\text { Sayan Gigani, Mochong }{ }^{12} \text {, North Rota; As Dudo }{ }^{12} \text {, East Rota; } \\
\text { Falagon, Songsong }{ }^{1} \text {, West Rota }\end{array}$ \\
\hline Chlorodesmis fastigiata (C. Agardh) Ducker & Mochong-As Matmos area ${ }^{6}$, North Rota \\
\hline Cladophorposis sundanensis Reinbold & Tatachok $^{1}$, North Rota; Puntan Sailigai ${ }^{1}$, West Rota \\
\hline Dictyosphaeria cavernosa (Forsskål) Børgesen & 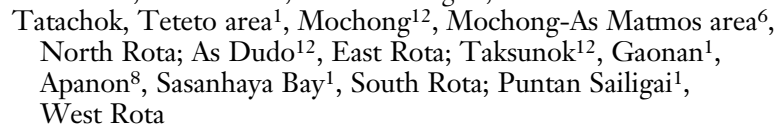 \\
\hline Dictyosphaeria versluysii Weber van Bosse & $\begin{array}{l}\text { Teteto area }{ }^{1} \text {, Sayan Gigani, Mochong }{ }^{12} \text {, North Rota; As } \\
\text { Dudo }{ }^{12} \text {, East Rota; Taksunok, West Punton Pona }{ }^{12} \text {, South } \\
\text { Rota; Falagon }{ }^{1} \text {, Esong }{ }^{12} \text {, West Rota }\end{array}$ \\
\hline Halimeda opuntia (L.) Lamouroux & $\begin{array}{l}\text { Tatachok, Tetoto area }{ }^{1} \text {, Mochong, Sayan Gigani }{ }^{12} \text {, Mochong-As } \\
\text { Matmos }^{6} \text {, North Rota; As Dudo } \\
\text { Apanon }^{8} \text {, South Rota }\end{array}$ \\
\hline Ulva lactuca L. & Sasanhaya Bay ${ }^{10}$, South Rota \\
\hline \multicolumn{2}{|l|}{ Phaeophyta } \\
\hline Chnoospora implexa Hering & Falagon ${ }^{1}$, West Rota \\
\hline Dictyota bartayresiana Lamouroux & Teteto area ${ }^{1}$, North Rota; Falagon ${ }^{1}$, West Rota \\
\hline Dictyota friabilis Setchel & Tatachok ${ }^{1}$, North Rota \\
\hline $\begin{array}{l}\text { Lobophora variegata (Lamouroux) Womersley } \\
\text { ex Oliveira }\end{array}$ & $\begin{array}{l}\text { Tatachok }{ }^{1} \text {, North Rota; Sasanhaya Bay }{ }^{1} \text {, South Rota; Falagon, } \\
\text { Songsong, Puntan Sailigai }{ }^{1} \text {, West Rota }\end{array}$ \\
\hline Padina minor Yamada & $\begin{array}{l}\text { Tatachok }{ }^{1} \text {, Mochong-As Matmos area }{ }^{6} \text {, North Rota; Gaonan }{ }^{1} \text {, } \\
\text { South Rota; Falagon }{ }^{1,2} \text {, West Rota }\end{array}$ \\
\hline $\begin{array}{l}\text { Sargassum cristaefolium C. Agardh } \\
\text { (formerly } S \text {. duplicatum) }\end{array}$ & Sasanhaya Bay ${ }^{1}$, South Rota; Songsong ${ }^{7}$, West Rota \\
\hline Sphacelaria tribuloides Meneghini & $\begin{array}{l}\text { Tatachok }^{1} \text {, North Rota; Sasanhaya Bay }{ }^{1} \text {, South Rota; Falagon }{ }^{1} \text {, } \\
\text { Apanon }^{8} \text {, West Rota }\end{array}$ \\
\hline Turbinaria ornata (Turner) J. Agassiz & $\begin{array}{l}\text { Tatachok }{ }^{1,4}, \text { Uyulan }^{9} \text {, Sayan Gigani } \\
\text { area }^{6}, \text { North Rota; As Dudo }^{12} \text {, East Rota; Apanonon } \\
\text { West Punton Pona }^{12}, \text { Gagani }^{8} \text {, Sasanhaya Bay } \\
\text { Esong }\end{array}$ \\
\hline \multicolumn{2}{|r|}{ 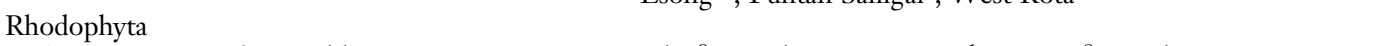 } \\
\hline Acanthophora spicifera (Vahl) Børgesen & Uyulan $^{9}$, North Rota; Gaonan ${ }^{1}$, Apanon ${ }^{8}$, South Rota \\
\hline Botryocladia skottsbergii (J. Agardh) Kylin & Mochong ${ }^{12}$, North Rota \\
\hline $\begin{array}{l}\text { Centroceras clavulatum (C. Agassiz) } \\
\text { Montagne }\end{array}$ & $\begin{array}{l}\text { Tatachok }{ }^{1} \text {, North Rota; Gaonan }{ }^{1}, \text { Apanon }^{8} \text {, Sasanhaya Bay }{ }^{1} \text {, } \\
\text { South Rota }\end{array}$ \\
\hline Champia parvula (Agassiz) Harvey & Puntan Sailigai ${ }^{1}$, West Rota \\
\hline $\begin{array}{l}\text { Gelidiella acerosa (Forsskål) Feldmann \& } \\
\text { Hamel }\end{array}$ & $\begin{array}{l}\text { Uyulan }^{9} \text {, Mochong-As Matmos area }{ }^{6} \text {, North Rota; Apanon }{ }^{8} \text {, } \\
\text { South Rota; Puntan Sailigai }{ }^{1} \text {, West Rota }\end{array}$ \\
\hline
\end{tabular}


TABLE 3 (continued)

\begin{tabular}{|c|c|}
\hline Classification & Location and Reference \\
\hline Gracilaria crassa Harvey & Gaonan $^{1}$, South Rota \\
\hline Gracillaria salicornia (C. Agardh) Dawson & Gaonan ${ }^{5}$, South Rota \\
\hline Hypnea musciformis (Wulfin) Lamouroux & $\begin{array}{l}\text { Teteto } 1,11 \text {, North Rota; Sasanhaya Bay }{ }^{1,11} \text {, South Rota; } \\
\text { Songsong, Puntan Sailigai }{ }^{1,11} \text {, West Rota }\end{array}$ \\
\hline Hypnea pannosa J. Agardh & Puntan Sailigai ${ }^{1}$, West Rota \\
\hline Hypnea spinella (C. Agardh) Kutzing & Esong $^{12}$, West Rota \\
\hline Jania capillacea Harvey & Mochon-As Matmos area ${ }^{6}$, North Rota; Apanon ${ }^{8}$, South Rota \\
\hline Tolypiocladia glomerulata (Agassiz) Schmitz & Gaonan $^{1}$, South Rota; Falagon ${ }^{1}$, West Rota \\
\hline \multicolumn{2}{|l|}{ Anthophyta } \\
\hline Enhalus acoroides (L.f) Royle & Apanon $^{8}$, South Rota; Falagon ${ }^{3}$, West Rota \\
\hline
\end{tabular}

References for locations: 1, Tsuda 1969; 2, U.S. Fish and Wildlife Service 1980; 3, Eldredge and Randall 1980; 4, Ellis-Neill and Neill 1985; 5, Meneses and Abbott 1987; 6, Randall and Smith 1988; 7, Tsuda 1988; 8, Wylie 1989; 9, Randall 1997; 10, Winzler and Kelly Consulting Engineers 2002; 11, Tsuda 2003; 12, this study.

been reported for other human-inhabited CNMI southern arc islands (Kolinski et al. 2001, 2004), all of which are large in size. Long-term fidelity to nearby resting and foraging areas is known for green turtles in the Pacific (Balazs 1980, Balazs et al. 1987, Limpus et al. 1994, Musick and Limpus 1997). Although potential food resources appear on all major coasts (Table 3), food abundance and its proximity to resting habitats at Rota remain unknown. Additional studies examining habitat specificity and usage in high turtle density areas may be warranted, because identification and protection of important marine habitats is considered critical to the maintenance and recovery of sea turtle populations (National Marine Fisheries Service and U.S. Fish and Wildlife Service 1998).

The projection of 118 turtles for Rota's nearshore reefs was similar to the estimate of 92 turtles generated for 2001 (Kolinski et al. 2004) using snorkel-tow and land-based survey data (Ilo and Manglona 2001). The closeness of the estimates over the 3-yr period suggests general consistency among the methodologies as well as short-term stability in turtle abundance at Rota. Frequent longterm monitoring and estimates of uncertainty will be needed to fully elucidate stability or trends in population status (see Bjorndal et al. 2005). Confidence intervals on future abundance estimates may be gained through incorporation of distance sampling (Buckland et al. 1993) in the towed-diver monitor- ing protocol. However, additional nearshore mapping of CNMI benthic depths will be necessary because accurate estimates on habitat area are lacking and will influence distance sampling analysis results.

United States recovery criteria for regional green turtle stocks require demonstration of statistically significant population increases in key foraging areas (National Marine Fisheries Service and U.S. Fish and Wildlife Service 1998). Although stock identifications have yet to be made for turtles foraging in Rota and other CNMI waters, there is some question as to whether Rota is "key" with regard to turtle utilization of regional nearshore habitats. Between 1,000 and 2,000 green turtles are believed to inhabit island reef areas in the southern arc of the CNMI. Approximately $92 \%$ of these turtles are located along the coasts of Tinian (54\%) and Saipan (38\%). Rota habitats appear to support $6 \%$ of turtles in CNMI southern arc waters (Kolinski et al. 2004), despite an island-reef perimeter similar in size to that of neighboring Tinian. There is no conspicuous distribution differentiation based on turtle size or maturity between Rota, Tinian, and Saipan (Kolinski et al. 2004, this study). Although observations of turtles $\leq 40 \mathrm{~cm}$ SCL indicate relatively recent and perhaps direct recruitment of pelagic transitioning juveniles at Rota (Hirth 1997, Musick and Limpus 1997, but see Limpus and Chaloupka 1997, Zug et al. 2002, Balazs and Chaloupka 2004, Chaloupka et al. 2004), Rota's relative contri- 
bution to supporting regional foraging turtles currently appears minor and indistinct.

The relevance of Rota to regional turtle monitoring may be in comparing Mariana Islands trends, because the capacity for increasing turtle numbers may be great where they are least abundant, assuming that appropriate habitat is available. Poaching in the Mariana Islands occurs (Wiles et al. 1990, McCoy 1997; Jay Gutierrez, Guam Division of Aquatic and Wildlife Resources, pers. comm.), but its influence on turtle populations remains unknown, highlighting a need for investigation and analysis. Future research should also focus on the genetic identification of green turtle stocks and the geographic extent of their dispersal (FitzSimmons et al. 1999, Kinan 2002), because foraging population demographics in the Marianas may depend primarily on impacts and processes that occur across international boundaries (Kolinski 1995, Gutierrez 2004).

\section{ACKNOWLEDGMENTS}

Thanks to Ken Barton and the crew of the NOAA ship R/V Oscar Elton Sette for the voyage and survey support. Data on turtles were collected by Rusty Brainard, Fran Castro, R.K.H., S.R.H., Peter Houk, S.P.K., Joe Laughlin, Trina Leberer, Machel Malay, Kate Moots, Doug Roberts, Robert Schroeder, Molly Timmers, Mike Trianni, and Brian Zgliczynski. Richard Seman, Ray Clarke, and Charles Karnella were instrumental in prioritizing turtle surveys as a cruise objective. John Naughton, Alan Everson, and Gerry Davis provided program support. Thanks to Jay Gutierrez at the Guam Division of Aquatic and Wildlife Resources, and the CNMI Division of Fish and Wildlife for information and local support. Gerry Davis, Ray Clarke, Charles Karnella, and two anonymous reviewers provided suggestions that improved the manuscript.

\section{Literature Cited}

Agastheesapillai, A., and R. Thiagarajan. 1979. Biology of the green turtle Chelonia mydas (Linnaeus) in the Gulf of Mannar and Palk Bay. J. Mar. Biol. Assoc. India 21:45-60.

Andre, J., E. Gyuris, and I. R. Lawler. 2005. Comparison of the diets of sympatric dugongs and green turtles on the Orman Reefs, Torres Strait, Australia. Wildl. Res. 32:53-62.

Balazs, G. H. 1980. Synopsis of biological data on the green turtle in the Hawaiian Islands. NOAA Tech. Mem. NOAA-TMNMFS-SWFSC-7.

. 1985. Status and ecology of marine turtles at Johnston Atoll. Atoll Res. Bull. 285:1-46.

Balazs, G. H., and M. Chaloupka. 2004. Spatial and temporal variability in somatic growth of green sea turtles (Chelonia mydas) resident in the Hawaiian Archipelago. Mar. Biol. (Berl.) 145:1043-1059.

Balazs, G. H., R. G. Forsyth, and A. K. H. Kam. 1987. Preliminary assessment of habitat utilization by Hawaiian green turtles in the resident foraging pastures. NOAA Tech. Mem. NOAA-TM-NMFSSWFC-71.

Balazs, G. H., M. R. Rice, N. Hoffman, S. K. K. Murakawa, D. M. Parker, and R. J. Shallenberger. 2005. Green turtle foraging and resting habitats at Midway Atoll: Significant findings over 25 years, 19752000. NOAA Tech. Mem. NOAA-TMNMFS-SEFSC-528:102-103.

Balazs, G. H., P. Siu, and J.-P. Landret. 1995. Ecological aspects of green turtles nesting at Scilly Atoll in French Polynesia. NOAA Tech. Mem. NOAA-TM-NMFS-SEFSC361:7-10.

Bjorndal, K. A., A. B. Bolton, and M. Y. Chaloupka. 2005. Evaluating trends in abundance of immature green turtles, Chelonia mydas, in the greater Caribbean. Ecol. Appl. 15:304-314.

Buckland, S. T., D. R. Anderson, K. P. Burnham, and J. L. Laake. 1993. Distance sampling: Estimating abundance of biological populations. Chapman and Hall, London.

Burke, V. J., S. J. Morreale, P. Logan, and E. A. Standora. 1991. Diet of green turtles (Chelonia mydas) in the waters of Long Island, N.Y. NOAA Tech. Mem. NOAATM-NMFS-SEFSC-301:140-143. 
Calvo, M. V., C. Lezama, M. LopezMendilaharsu, A. Fallabrino, and J. Coll. 2003. Stomach content analysis of stranded juvenile green turtles in Uruguay. NOAA Tech. Mem. NOAA-TM-NMFS503:203-204.

Chaloupka, M., C. Limpus, and J. Miller. 2004. Green turtle somatic growth dynamics in a spatially disjunct Great Barrier Reef metapopulation. Coral Reefs 23:325-335.

Eldredge, L. G. 1983. Summary of environmental and fishing information on Guam and the Commonwealth of the Northern Mariana Islands: Historical background, description of the islands, and review of the climate, oceanography, and submarine topography. NOAA Tech. Mem. NOAATM-NMFS-SWFC-40.

Eldredge, L. G., and R. H. Randall. 1980. Atlas of the reefs and beaches of Saipan, Tinian and Rota. Office of Coastal Resources Management of the Commonwealth of the Northern Marianas.

Ellis-Neill, L., and J. B. Neill. 1985. Environmental assessment of the reef-flat platform habitat in the Tatachog Park area, Rota, CNMI. Unpublished Report for the Coastal Resources Management Office, Saipan, CNMI. University of Guam Marine Laboratory, Guam. (Available from Coastal Resources Management Office, Saipan.)

Evans, D. L., K. B. Cooper, and W. G. Barron Jr. 2002. 2000 census of population and housing: The Commonwealth of the Northern Mariana Islands. Population and Housing Profiles, 2000. U.S. Census Bureau, Department of Commerce.

Ferreira, M. B., M. Garcia, B. Jupp, and A. Al-Kiyumi. 2003. Feeding ecology of the green turtle, Chelonia mydas, at Ra's $\mathrm{Al}$ Hadd, Arabian Sea, Sultanate of Oman. NOAA Tech. Mem. NOAA-TM-NMFSSEFSC-503:205-206.

FitzSimmons, N., C. Moritz, and B. W. Bowen. 1999. Population identification. Pages 72-79 in K. L. Eckert, K. A. Bjorndal, F. A. Abreu-Grobois, and M. Donnelly, eds. Research and management techniques for the conservation of sea tur- tles. IUCN/SSC Marine Turtle Specialist Group Publication No. 4.

Forbes, G. A. 1996. The diet of the green turtle in an algal-based coral reef communityHeron Island, Australia. Ph.D. diss., James Cook University, Townsville, Australia.

Grout, D. 1997. Summary of USFWS Rota sea turtle nesting surveys. Unpublished notes, U.S. Fish and Wildlife Service, Honolulu, Hawai'i. (Available from U.S. Fish and Wildlife Service, Honolulu.)

Gutierrez, J. 2004. Guam sea turtle recovery annual progress report. Unpublished report. Division of Aquatic and Wildlife Resources, Guam. (Available from Division of Aquatic and Wildlife Resources, Guam.)

Hirth, H. F. 1997. Synopsis of the biological data on the green turtle Chelonia mydas (Linnaeus 1758). U.S. Fish Wildl. Serv. Biol. Rep. 97 (1).

Holloway-Adkins, K. G., and L. M. Ehrhart. 2005. A comparison of habitat, foraging ecology and the biotoxin okadaic acid in five Florida populations of Chelonia mydas. NOAA Tech. Mem. NOAA-TM-NMFSSEFSC-528:61-63.

Ilo, L. I., and J. M. Manglona. 2001. Rota turtle assessment report. Unpublished report. Division of Fish and Wildlife, Commonwealth of the Northern Mariana Islands, Saipan. (Available from Division of Fish and Wildlife, CNMI, Saipan.)

Kenyon, J. C., R. E. Brainard, R. K. Hoeke, F. A. Parrish, and C. B. Wilkinson. In press. Towed-diver surveys, a method for mesoscale spatial assessment of benthic reef habitat: A case study at Midway Atoll in the Hawaiian Archipelago. Coastal Manage.

Kinan, I., ed. 2002. Proceedings of the western Pacific sea turtle cooperative research and management workshop, 5-8 February 2002, Honolulu, Hawai'i, USA. Western Pacific Regional Fishery Management Council, Honolulu, Hawai'i.

Kolinski, S. P. 1995. Migrations of the green turtle, Chelonia mydas, breeding in Yap State, Federated States of Micronesia. Micronesica 28:1-8.

Kolinski, S. P., R. K. Hoeke, S. R. Holz- 
warth, and P. S. Vroom. 2005. Sea turtle abundance at isolated reefs of the Mariana Archipelago. Micronesica 37:287-296.

Kolinski, S. P., L. I. Ilo, and J. M. Manglona. 2004. Green turtles and their marine habitats at Tinian and Aguijan, with projections of resident turtle demographics in the southern arc of the Commonwealth of the Northern Mariana Islands. Micronesica 37:95-116.

Kolinski, S. P., D. M. Parker, L. I. Ilo, and J. K. Ruak. 2001. An assessment of sea turtles and their marine and terrestrial habitats at Saipan, Commonwealth of the Northern Mariana Islands. Micronesica 34:55-72.

Limpus, C., and M. Chaloupka. 1997. Nonparametric regression modeling of green sea turtle growth rates (southern Great Barrier Reef). Mar. Ecol. Prog. Ser. 149:23-34.

Limpus, C. J., P. J. Couper, and M. A. Reed. 1994. The green turtle Chelonia mydas in Queensland: Population structure in a warm temperate feeding area. Mem. Queensl. Mus. 35:139-154.

Limpus, C. J., D. J. Limpus, K. E. Arthur, and C. J. Parmenter. 2005. Monitoring green turtle population dynamics in Shoalwater Bay: 2000-2004. Great Barrier Reef Marine Park Authority Res. Publ. 83.

Lopez-Mendilaharsu, M., S. C. Gardner, and J. A. Seminoff. 2003. Feeding ecology of the East Pacific green turtle (Chelonia mydas agassizii) in Bahia Magdalena, B.C.S., Mexico. NOAA Tech. Mem. NOAATM-NMFS-SEFCS-503:213-214.

Lopez-Mendilaharsu, M., S. C. Gardner, J. A. Seminoff, and R. Riosmena-Rodriguez. 2005. Identifying critical foraging habitats of the green turtle (Chelonia mydas) along the Pacific coast of the Baja California peninsula, Mexico. Aquatic Conserv: Mar. Freshwater Ecosyst. 15:259-269.

Makowski, C., J. A. Seminoff, and M. Salmon. 2006. Home range and habitat use of juvenile Atlantic green turtles (Chelonia mydas L.) on shallow reef habitats in Palm Beach, Florida, USA. Mar. Biol. (Berl.) 148:1167-1179.

McCoy, M. A. 1997. The traditional and cer- emonial use of the green turtle (Chelonia mydas) in the Northern Mariana Islands with recommendations for its use in cultural events and education. Unpublished report prepared for the Western Pacific Regional Fishery Management Council and the University of Hawai'i Sea Grant College Program, Honolulu, Hawai'i. (Available from the Western Pacific Regional Fishery Management Council.)

Mendonca, M. T. 1983. Movements and feeding ecology of immature green turtles (Chelonia mydas) in a Florida lagoon. Copeia 1983:1013-1023.

Meneses, I., and I. A. Abbott. 1987. Gracilaria and Polycavernosa (Rhodophyta) from Micronesia. Micronesica 20:187-200.

Mortimer, J. A. 1981. The feeding ecology of the West Caribbean green turtle (Chelonia mydas) in Nicaragua. Biotropica 13:49-58.

Musick, J. A., and C. J. Limpus. 1997. Habitat utilization and migration in juvenile sea turtles. Pages 137-163 in P. L. Lutz and J. A. Musick, eds. The biology of sea turtles. CRC Press, Boca Raton, Florida.

National Marine Fisheries Service and U.S. Fish and Wildlife Service. 1998. Recovery plan for U.S. Pacific populations of the green turtle (Chelonia mydas). National Marine Fisheries Service, Silver Spring, Maryland.

Preskitt, L. B., P. S. Vroom, and C. M. Smith. 2004. A rapid ecological assessment (REA) quantitative survey method for benthic algae using photoquadrats with scuba. Pac. Sci. 58:201-209.

Pritchard, P. C. H. 1982. Marine turtles of Micronesia. Pages 263-272 in K. A. Bjorndal, ed. Biology and conservation of sea turtles. Proceedings of the world conference on sea turtles. Smithsonian Institution Press, Washington, D.C.

Pultz, S., D. O'Daniel, S. Krueger, H. McSharry, and G. Balazs. 1999. Marine turtle survey on Tinian, Mariana Islands. Micronesica 32:85-94.

Randall, R. H. 1997. A biological and geological assessment of the Holocene and modern fringing reef system developed along Uyulan Beach, Rota, Mariana Islands. Unpublished report prepared for IOTA Part- 
ners, Bellevue, Washington. (Available through the U.S. Army Corps of Engineers, Honolulu District.)

Randall, R. H., and B. D. Smith. 1988. A reconnaissance marine survey of the Mochong-As Matmos coastal area of Rota in the Mariana Islands. Univ. Guam Mar. Lab. Environ. Surv. Rep. No. 21.

Read, M. A., and C. J. Limpus. 2002. The green turtle, Chelonia mydas, in Queensland: Feeding ecology of immature turtles in Moreton Bay, southeastern Queensland. Mem. Queensl. Mus. 48:207-214.

Russell, D. J., and G. H. Balazs. 2000. Identification manual for dietary vegetation of the Hawaiian green turtle Chelonia mydas. NOAA Tech. Mem. NOAA-TM-NMFSSWFSC-294.

Russell, D. J., G. H. Balazs, R. C. Phillips, and A. K. H. Kam. 2003. Discovery of the sea grass Halophila decipiens (Hydrocharitaceae) in the diet of the Hawaiian green turtle, Chelonia mydas. Pac. Sci. 57:393-397.

Sanchez, F. A., and D. D. Quiroga. 2005. Determination of feeding habits and behavior of the Pacific black turtle (Chelonia mydas agassizii) in Gorgona National Park, Departamento del Cauca, Columbia. NOAA Tech. Mem. NOAA-TM-NMFS-SEFSC528:303-305.

Sara, S. K., C. M. Bravo, X. Velez-Zuazo, and M. W. de Castro. 2005. Green turtle (Chelonia mydas agassizii) diet differences in two Peruvian coastal localities. NOAA Tech. Mem. NOAA-TM-NMFS-SEFSC528:305-307.

Searle, L. 2003. Diet of green turtles (Chelonia mydas) captured in the Robinson Point foraging ground, Belize. NOAA Tech. Mem. NOAA-TM-NMFS-SEFSC503:228-229.

Seminoff, J. A., A. Resendiz, and W. J. Nichols. 2002. Diet of East Pacific green turtles (Chelonia mydas) in the central Gulf of California, Mexico. J. Herpetol. 36:447453.

Tsuda, R. T. 1969. Biological results of an expedition to Rota, Mariana Islands. Misc. Rep., Univ. Guam, Div. Biosci. Mar. Stud., Guam.
1988. Sargassum from Micronesia. Pages 59-63 in I. A. Abbott, ed. Taxonomy of economic seaweeds with reference to some Pacific and Caribbean species. Vol. 2. California Sea Grant College Program Report No. T-CSGCP-018.

. 2003. Checklist and bibliography of the marine benthic algae from the Mariana Islands (Guam and CNMI). Univ. Guam Mar. Lab. Tech. Rep. No. 107.

U.S. Fish and Wildlife Service. 1980. Rota Harbor project, Commonwealth of the Northern Mariana Islands. Unpublished report, U.S. Fish and Wildlife Service, Division of Ecological Services, Honolulu, Hawai'i. (Available from U.S. Fish and Wildlife Service, Honolulu.)

Uzcategui, R. F., H. B. Garrido, T. L. Fuenmayor, and J. R. Hernandez 2005. Stomach content analysis of a green turtle (Chelonia mydas) found in Porshoure, Zulia State, Venezuela. NOAA Tech. Mem. NOAA-TM-NMFS-SEFSC-528: 346-347.

Wells, S. M., and M. D. Jenkins. 1988. Northern Mariana Islands. Pages 241-246 in S. M. Wells and M. D. Jenkins, eds. Coral reefs of the world. Vol. 3. Central and western Pacific. IUCN Conservation Monitoring Center and the United $\mathrm{Na}-$ tions Environmental Programme.

Wiles, G. J., A. B. Amerson Jr., and R. E. Beck Jr. 1989. Notes on the herpetofauna of Tinian, Mariana Islands. Micronesica 22:107-118.

Wiles, G. J., G. H. Rodda, R. H. Fritts, and E. M. Taisacan. 1990. Abundance and habitat use of reptiles on Rota, Mariana Islands. Micronesica 23:153-166.

Winzler and Kelly Consulting Engineers. 2002. Permit application package for Rota East Harbor rehabilitation project. Application prepared for the CNMI Department of Public Works, Saipan. (Available through the U.S. Army Corps of Engineers, Honolulu District.)

Wylie, C. R. 1989. A quantitative assessment of macroalgae. Pages 28-34 in B. D. Smith, R. H. Randall, S. S. Amesbury, E. E. Irish, and C. R. Wylie, A marine survey of the Apanon coastal environment, 
Talakhaya area, Rota, Mariana Islands. Univ. Guam Mar. Lab. Environ. Surv. Rep. No. 22.

Zug, G. R., G. H. Balazs, J. A. Wetherall, and
D. M. Parker. 2002. Age and growth of Hawaiian green sea turtles (Chelonia mydas): An analysis based on skeletochronology. Fish. Bull. 100:117-127. 